\title{
Taxonomical studies on the lichen genus Platygramme (Graphidaceae) in China
}

\author{
Ze-Feng JIA and Klaus KALB
}

\begin{abstract}
In the present paper, seven species of the lichen genus Platygramme are reported from China. Two of these, Platygramme pudica and P. platyloma, are new to China and two species, Platygramme hainanensis and $P$. lueckingii, both from a tropical rain forest in Hainan Island, are described as new to science. The new species belong to a group within Platygramme, which is characterized by concealed discs, while the type species, P. caesiopruinosa, and some others have widely open discs. Descriptions and the known distribution of each species are given and a working key to the Chinese species is provided.
\end{abstract}

Key words: lichenized fungi, lirellae, Ostropales, taxonomy

Accepted for publication 17 September 2012

\section{Introduction}

The family Graphidaceae, with 1200 species (now also including Thelotremataceae), is one of the largest groups of crustose lichens and has a wide distribution in tropical regions. The family belongs to Ostropales, which is the largest order within Ostropomycetidae (Lumbsch \& Huhndorf 2007; Kirk et al. 2008; Mangold et al. 2008). Staiger (2002) revised the spore-based generic system established by Müller Argoviensis (1880a, $b$, 1882) for the family Graphidaceae, and reintroduced several genera with a revised concept, including the genus Platygramme Fée. Platygramme is a tropical and subtropical taxon, which is characterized by lirelliform ascomata, an apically or laterally carbonized proper exciple often wedge-like in appearance, an inspersed hymenium and greyish to

Z-F. Jia: College of Life Sciences, Shandong Agricultural University, Taian, 271018, Shandong Province, China.

K. Kalb (corresponding author): Lichenologisches Institut Neumarkt, Im Tal 12, D-92318 Neumarkt, Germany and University of Regensburg, Institute for Botany, Universitätsstraße 31, D-93040 Regensburg, Germany. Email: klaus.kalb@arcor.de pale brown transversely septate or muriform ascospores.

In a study of the genus Platygramme for the Flora Lichenum Sinicorum, Miao et al. (2007) reported two species from China, namely $P$. discurrens (Nyl.) Staiger, which was also reported as Graphis discurrens from Hong Kong (Nylander 1863), and P. pachyspora (Redinger) Staiger, described as a new record for China. Subsequently, Platygramme muelleri was added by $\mathrm{Li}$ (2010). In the present paper, Platygramme pudica and P. platyloma are reported from China for the first time, and the two species Platygramme hainanensis and $P$. lueckingii are described as new to science.

\section{Materials and Methods}

The lichen specimens were examined with a dissecting microscope (TECH XTS-20 and AIGO Digital Viewer GE-5) and compound microscope (OLYMPUS CHB213) for morphological and anatomical studies. Handcut sections mounted in tap water were routinely examined. Amyloidity of the ascospores was tested using Lugol's solution. Spot tests with $\mathrm{KOH}(20 \%)$ were performed on the thallus surface and on thin thallus sections. The chemistry was determined by thin-layer chromatography (TLC) using standard methods. 


\section{Key to the species of Platygramme from China}

1 Ascospores with transverse septa, $5-25(-30) \times 5-8 \mu \mathrm{m} \ldots \ldots \ldots \ldots \ldots \ldots$ . . . . . . . . . . . . . Platygramme discurrens (Nyl.) Staiger

Ascospores submuriform or muriform $\ldots \ldots \ldots \ldots \ldots \ldots \ldots \ldots \ldots \ldots \ldots$

2(1) Ascospores 1 per ascus, longer than $100 \mu \mathrm{m}$ when mature . . . . . . . . . 3

Ascospores 2-8 per ascus, shorter than $100 \mu \mathrm{m}$ when mature . . . . . . . . . . . 5

3(2) Echinocarpic acid present, ascospores $150-180 \times 18-25 \mu \mathrm{m}$; disc concealed, labia covered by thallus . . . . . . . . . . . . . . . . . . . . . . . . . Platygramme pudica (Mont. \& Bosch.) M. Nakan. \& Kashiw.

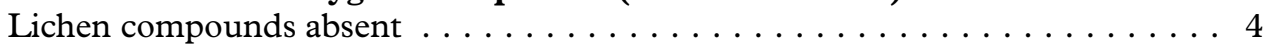

4(3) Lirellae conspicuously open, disc visible; ascospores $110-160 \times 18-25 \mu \mathrm{m} \ldots \ldots .$. . . . . . . . . . . . . . . . Platygramme muelleri (A. W. Archer) Staiger

Lirellae closed to slightly open, disc concealed, with thick labia; ascospores $120-$ $180 \times 25-35 \mu \mathrm{m}$.

Platygramme platyloma (Müll. Arg.) M. Nakan. \& Kashiw.

5(2) Ascospores submuriform, 45-80 × 12-18 $\mu \mathrm{m}$; disc very narrow . . . . . . . . . . $\ldots \ldots \ldots \ldots \ldots$. . . . . . . . . . . Redygramme pachyspora (Redinger Ascospores muriform, shorter than $50 \mu \mathrm{m}$; disc concealed, labia covered by thallus. . 6

6(5) Ascospores 8 per ascus, $30-50 \times 6 \cdot 5-13.0 \mu \mathrm{m} \ldots \ldots \ldots \ldots \ldots \ldots$ . . . . . . . . . . . . . . Platygramme hainanensis Z.F. Jia \& Kalb Ascospores $2(4)$ per ascus, $35-45 \times 11 \cdot 0-15 \cdot 5 \mu \mathrm{m} \ldots \ldots \ldots \ldots \ldots$ Platygramme lueckingii Z.F. Jia \& Kalb

\section{The Species}

\section{Platygramme hainanensis Z.F. Jia \& Kalb sp. nov.}

\section{MycoBank No: MB801119}

Sicut $P$. australiensis sed sporis minoribus differt.

Typus: China, Hainan Island, Mt. Wuzhishan, $18^{\circ} 92^{\prime} \mathrm{N}, 109^{\circ} 68^{\prime} \mathrm{E}$, alt. $680 \mathrm{~m}, 28$ August 2008, coll. fing $L i$ HN081281 (HMAS-L-holotypus).

(Fig. 1A-D)

Thallus corticolous, crustose, pale white to greenish, unevenly thickened, tightly attached to the substratum.

Apothecia elongate, 1-10 $\mathrm{mm}$ long, $0 \cdot 2-$ $0.4 \mathrm{~mm}$ wide, simple or rarely slightly branched, prominent, with basal thalline margin, black, curved and straight, often rounded at the ends, not striate, scattered over the thallus, labia covered with thin white pruina; disc concealed. Proper exciple apically to laterally carbonized. Epithecium 8-10 $\mu \mathrm{m}$ thick, brownish. Hymenium colourless, inspersed, 130-180 $\mu \mathrm{m}$ high, I-. Paraphyses unbranched, filiform, up to $1.0-1.5 \mu \mathrm{m}$ wide. Asci cylindrical, 110-150 × 15-25 $\mu \mathrm{m}, 8$-spored. Ascospores greyish brown, oblong to ellipsoid, muriform, 8-9 $\times 1-3-$ locular, 30-50 × 6.5-13.0 $\mu \mathrm{m}$, I+ red-brown. Hypothecium brownish, 8-15 $\mu \mathrm{m}$ high.

Chemistry. No lichen compounds detected.

Etymology. The specific epithet 'hainanensis' refers to the type locality of the new species, Hainan Island.

Remarks. Platygramme hainanensis is characterized by the conspicuous, closed, prominent, apically-carbonized lirellae with closed disc and thick labia, the muriform ascospores (30-50 $\mu \mathrm{m}$ long), and by the absence of lichen compounds. It is distinguished from $P$. australiensis Staiger \& Malthes-Leicht by smaller ascospores.

Additional specimens examined. China: Hainan: Mt. Wuzhishan, 790 m, 2009, Li fing HN216 (HMAS-L); 730 m, 2009, Li fing HN233 \& HN 233-1 (HMAS-L). 

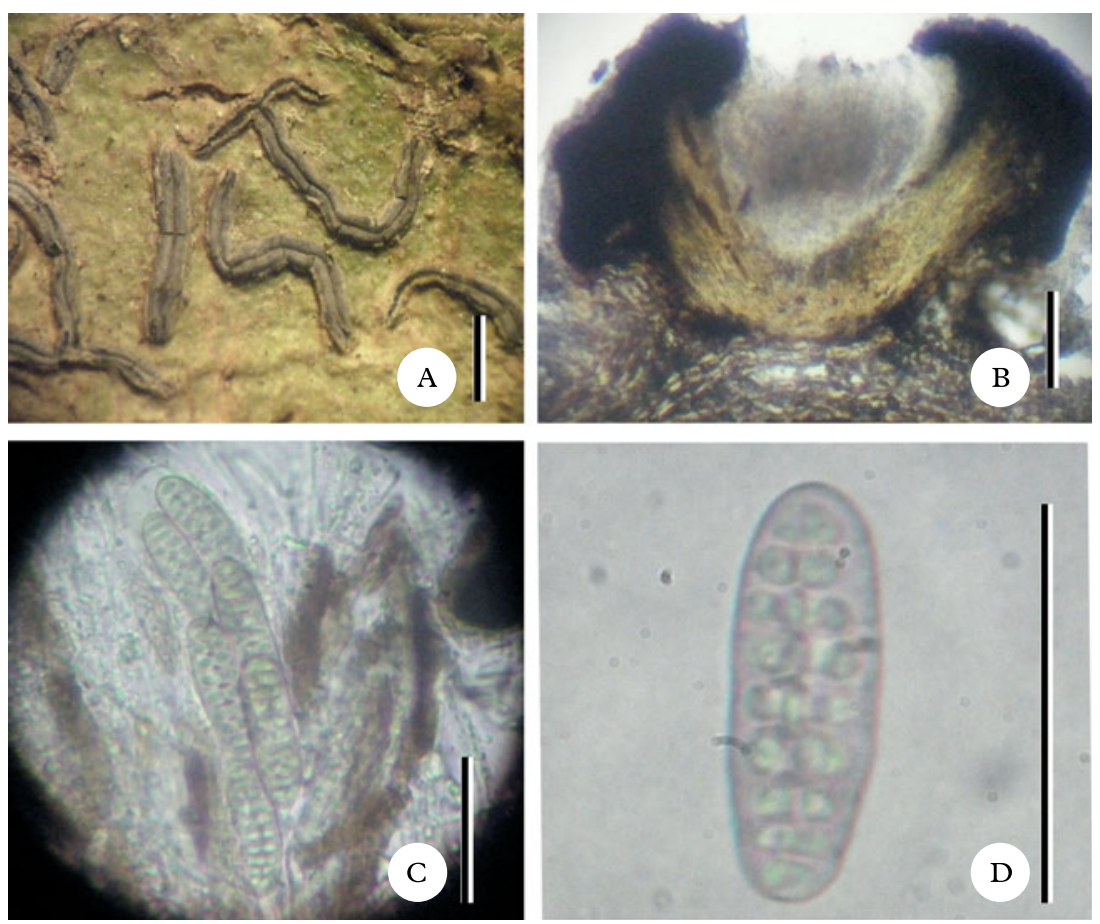

FIG. 1. Platygramme hainanensis (Fing Li HN081281). A, habit; B, cross-section of an apothecium; C, ascus containing ascospores; $\mathrm{D}$, ascospore. Scales: $\mathrm{A}=1 \mathrm{~mm} ; \mathrm{B}=50 \mu \mathrm{m} ; \mathrm{C}=50 \mu \mathrm{m} ; \mathrm{D}=50 \mu \mathrm{m}$. In colour online.

Platygramme lueckingii Z.F. Jia \& Kalb sp. nov.

\section{MycoBank No: MB801120}

Sicut $P$. hainanensis sed ascis 2 -sporis differt.

Typus: China, Hainan Island, Mt. Jianfengling, $18^{\circ} 71^{\prime} \mathrm{N}, 108^{\circ} 83^{\prime} \mathrm{E}$, alt. $740 \mathrm{~m}, 1$ October, 2008, $L i$ fing HN081395 (HMAS-L-holotypus).

(Fig. 2A-C)

Thallus corticolous, crustose, yellowish green to greenish, thin, tightly attached to the substratum.

Apothecia elongate, lirelliform, 1-5 mm long, $0.3-0.4 \mathrm{~mm}$ wide, simple, often branched, erumpent to prominent, with basal thalline margin, black, curved and straight, often rounded at the ends, not striate, scattered over the thallus, labia covered with white pruina; disc concealed. Proper exciple apically wedge-shaped, carbonized. Epithecium 8-10 $\mu \mathrm{m}$ thick, brownish. Hymenium colourless, inspersed, 110-160 $\mu \mathrm{m}$ high, I-. Paraphyses unbranched, filiform, up to $1.0-1.5 \mu \mathrm{m}$ wide. Asci cylindrical, 90$110 \times 13-25 \mu \mathrm{m}, 2$-spored. Ascospores greyish, oblong to ellipsoid, muriform, $8-9 \times 1-$ 3-locular, 35-45 × 11.0-15.5 $\mu \mathrm{m}$, I+ weakly blue. Hypothecium brownish, 8-15 $\mu \mathrm{m}$ high.

Chemistry. No lichen compounds detected.

Etymology. The new species is named in honour of our colleague and friend Dr Robert Lücking for his many contributions to the knowledge of Graphidaceae.

Remarks. Platygramme lueckingii is characterized by the conspicuous, closed, erumpent to prominent, apically carbonized lirellae with closed disc and thick labia, the muriform ascospores (35-45 $\mu \mathrm{m}$ long), and the absence of lichen products. It is distinguished from $P$. hainanensis by the 2 -spored asci. At present the new species is known only from Mt. Jianfengling, Hainan Island, which is situated in the tropical parts of China. 

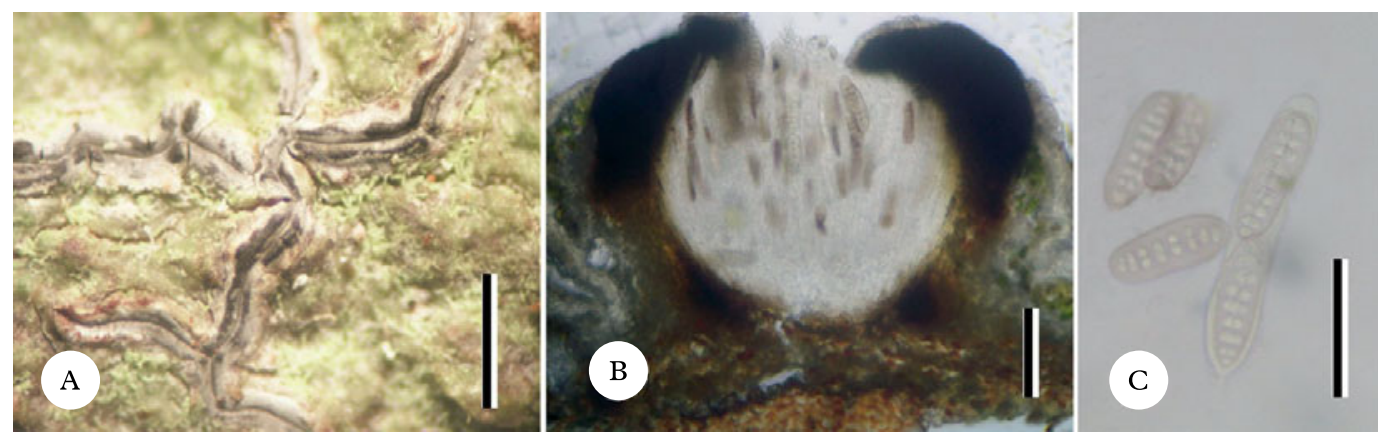

FIG. 2. Platygramme lueckingii (Li fing HN081395). A, habit; B, cross-section of an apothecium; C, ascospores. Scales: $\mathrm{A}=1 \mathrm{~mm} ; \mathrm{B}=50 \mu \mathrm{m} ; \mathrm{C}=50 \mu \mathrm{m}$. In colour online.

\section{Platygramme discurrens (Nyl.) Staiger}

Biblioth. Lichenol. 85: 361 (2002).-Graphis discurrens Nyl., Ann. Sci. Nat., Bot. sér. 4, 19: 358 (1863b).Phaeographina discurrens (Nyl.) Müll. Arg., Flora, 65: 604 (1882).

\section{(Fig. 3A \& B)}

Thallus corticolous, yellow-green, thin, surface shiny, flat to somewhat rough.

Apothecia lirelliform, greyish black, often branched, conspicuous, prominent, $1-6 \mathrm{~mm}$ long and $0 \cdot 1-0.3 \mathrm{~mm}$ wide, lips closed, with thin white pruina, without thalline margin. Disc concave, very narrow. Proper exciple convergent, apically carbonized. Hymenium inspersed, 70-100 $\mu \mathrm{m}$ high. Ascospores 8 per ascus, pale brown, elongate, with transverse septa only, 4-7-locular, $15-25(-30) \times 5-8$ $\mu \mathrm{m}, \mathrm{I}+$ red-brown.

Chemistry. Stictic acid (major) and constictic acid (trace).

Remarks. Platygramme discurrens is characterized by the closed, conspicuously prominent, apically carbonized lirellae with closed disc and thick labia, the small ascospores (15-25 $\mu \mathrm{m}$ long) with transverse septa, and the presence of stictic acid. The type specimen of this species was collected in Hong Kong and originally described in the genus Graphis (Nylander 1863), but later transferred to the genus Platygramme by Staiger (Staiger 2002).
Specimens examined. China: Hainan: Mt. Wuzhishan, 680-800 m, 2009, Li fing HN220-1, HN226-1 (HMASL). Yunnan: Menglun County, $560 \mathrm{~m}, 1981$, fiang YuMei 1015-3 (HMAS-L); $650 \mathrm{~m}$, 1981, Fiang Yu-Mei 949 (HMAS-L). Fujian: Mt. Wuyi, Wanmulin, 250 m, 2004, fia Ze-Feng FJ360 \& Wei Xin-Li 0189 (LHS).

\section{Platygramme muelleri (A. W. Archer) Staiger}

Biblioth. Lichenenol. 85: 364 (2002).-Phaeographina muelleri Archer, Telopea 8(4): 473 (2000).-Phaeographina caesiopruinosa var. monospora Müller Arg., Bull. Herb. Boissier 3(7): 322 (1895c).

\section{(Fig. 3C \& D)}

Thallus corticolous, greenish yellow, thin, surface matt, somewhat rough.

Apothecia lirelliform, black, single and sometimes branched, conspicuous, sessile, $1 \cdot 0-2 \cdot 5$ $\mathrm{mm}$ long, $0.3-0.6 \mathrm{~mm}$ wide, lips inconspicuous, with a distinct thalline margin. Disc open, black, with a thin pruina. Proper exciple apically carbonized, wedge-shaped. Hymenium inspersed, 150-200 $\mu \mathrm{m}$ high. Ascospores 1 per ascus, pale brown, elongate, densely muriform, $28-40 \times 4-7$-locular, 110-160 × 18$25 \mu \mathrm{m}, \mathrm{I}+$ red-brown.

Chemistry. No lichen compounds detected.

Remarks. Platygramme muelleri is characterized by the conspicuous, open, apically carbonized lirellae with opened disc and delicate labia, the large muriform ascospores (110-160 $\mu \mathrm{m}$ long), and the absence of 

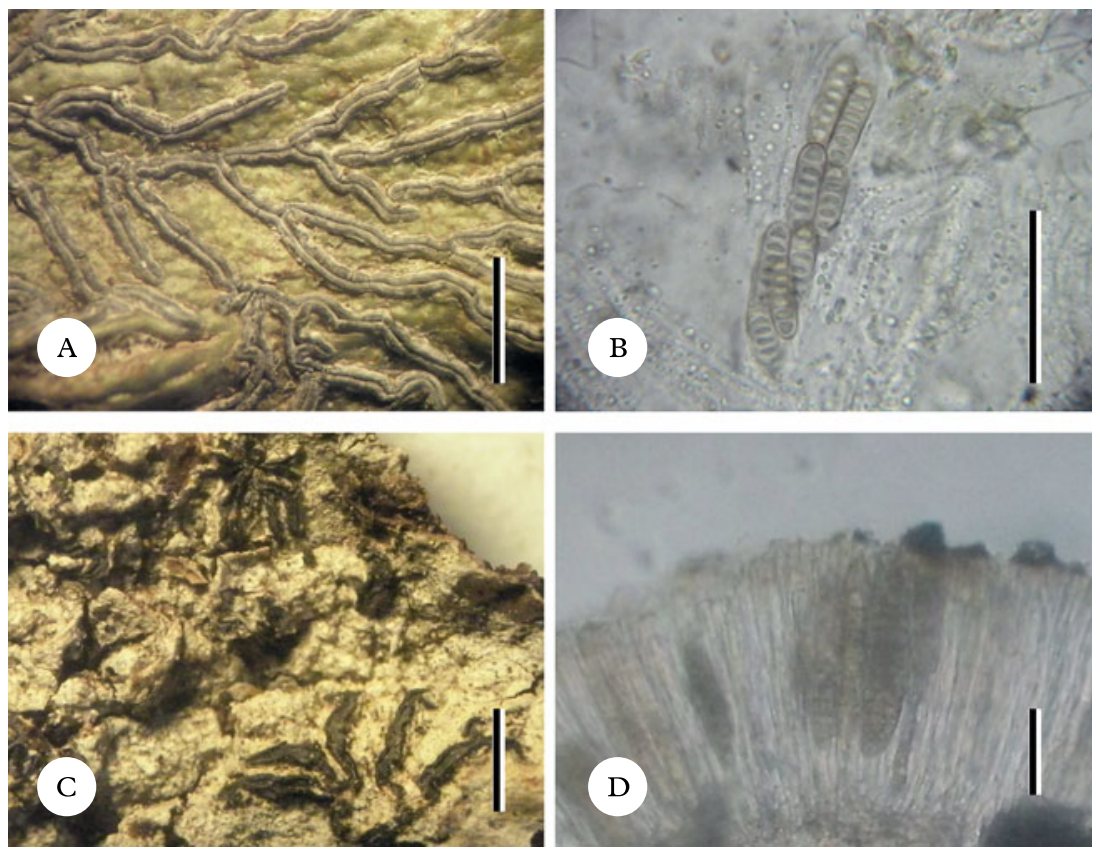

FIG. 3. Platygramme discurrens (Fing Li HN081281). A, habit; B, cross-section of an apothecium. P. muelleri (Fing Li HN081281). C, habit; D, cross-section of an apothecium. Scales: A \& C = $1 \mathrm{~mm} ; \mathrm{B}=50 \mu \mathrm{m} ; \mathrm{D}=50 \mu \mathrm{m}$. In colour online.

lichen compounds. It was reported from China by Li (2010).

Specimens examined. China: Yunnan: Weixi County, 1900 m, 1981, Wang Xian-Ye et al. 3749 (HMAS-L). Hainan: Mt. Wuzhishan, $700 \mathrm{~m}, 2009$, Li fing HN09096 (HMAS-L); Mt. Jianfengling, 2008, Li fing HN081330 \& HN081400 (HMAS-L).

\section{Platygramme pachyspora (Redinger) Staiger}

Biblioth. Lichenol., 85: 364 (2002).-Phaeographis pachyspora Redinger, Ark. Bot. 27 A (3): 77 (1935).

(Fig. 4 A-C)

Thallus corticolous, grey-greenish, thin, surface matt, smooth to rough.

Apothecia lirelliform, greyish black, single, conspicuous, erumpent to sessile, $1-7 \mathrm{~mm}$ long, $0 \cdot 2-0 \cdot 4 \mathrm{~mm}$ wide, with thalline margin. Disc very narrow. Proper exciple convergent, laterally carbonized, wedge-shaped. Hymenium inspersed, 150-170 $\mu \mathrm{m}$ high. Ascospores 8 per ascus, pale brown, elongate, submuriform, 10-12 × 1-2-locular, (45-)50$80 \times 12-18 \mu \mathrm{m}, \mathrm{I}+$ red-brown.

Chemistry. No lichen compounds detected.

Remarks. Platygramme pachyspora is characterized by the wedge-shaped, carbonized lateral exciple with closed disc and thick labia, the submuriform ascospores $(45-80 \mu \mathrm{m}$ long), and the absence of lichen compounds. It was first reported from China by Miao (Miao et al. 2007).

Specimen examined. China: Fujian: Mt. Wuyi, $250 \mathrm{~m}$, 2004, fia Ze-Feng FJ 370 (LHS).

\section{Platygramme platyloma (Müll. Arg.) M. Nakan. \& Kashiw.}

Bull. Natn. Sci. Mus., Tokyo, Ser. B, 29: 89 (2003).Phaeographis platyloma Müll. Arg., Flora, 65: 389 (1882).

(Fig. 4D-F)

Thallus corticolous, yellow-greenish, thin, surface matt, rough. 

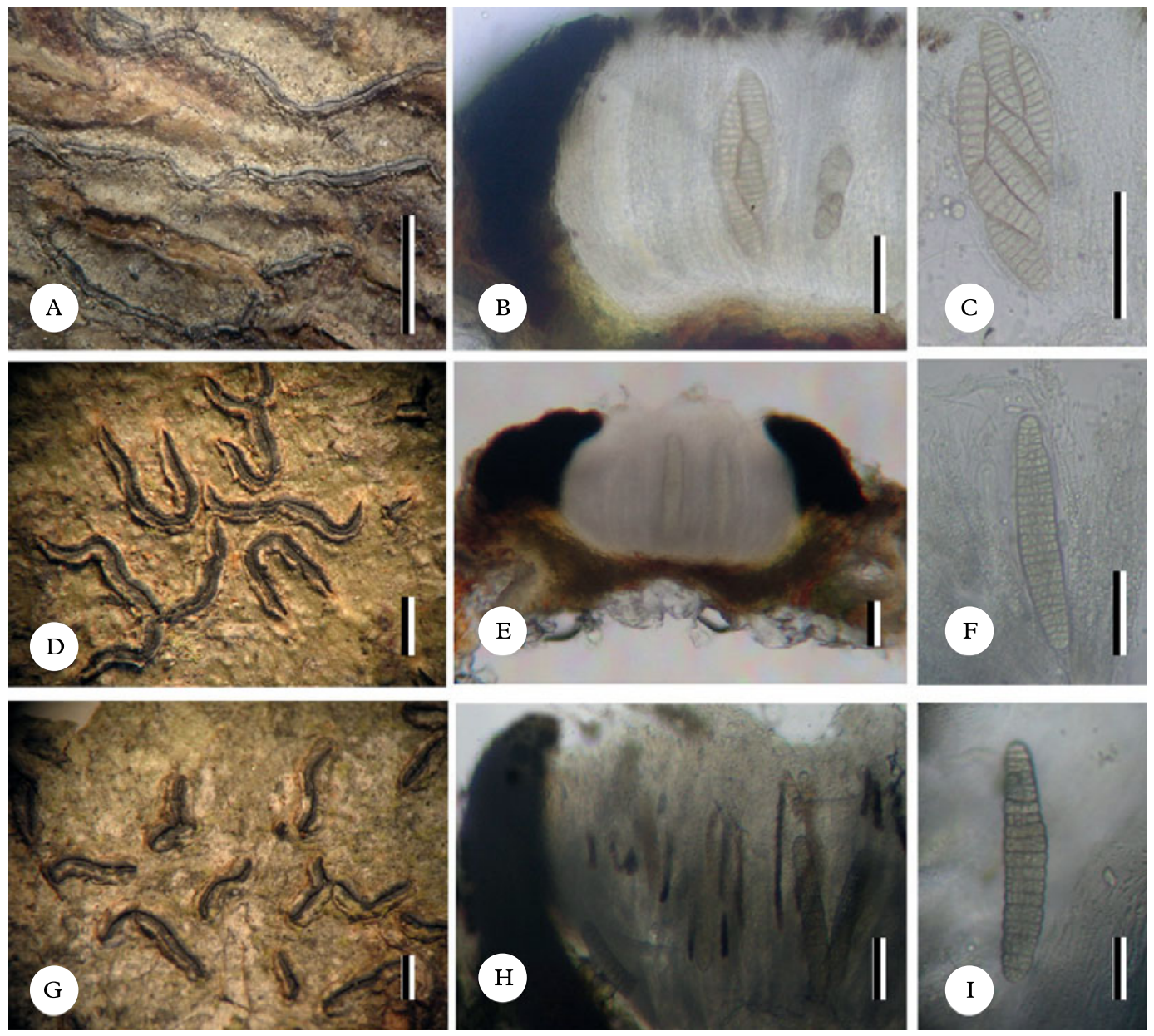

FIG. 4. Platygramme pachyspora; A, habit; B, cross-section of an apothecium; C, ascospores. P. platyloma; D, habit; E, cross-section of an apothecium; F, ascospore. P. pudica; G, habit; H, cross-section of an apothecium; I, ascospore. Scales: A, D \& G = $1 \mathrm{~mm} ; \mathrm{B}, \mathrm{E} \& \mathrm{H}=50 \mu \mathrm{m} ; \mathrm{C}, \mathrm{F} \& \mathrm{I}=50 \mu \mathrm{m}$. In colour online.

Apothecia lirelliform, conspicuous, scattered, prominent, black, single, $1 \cdot 0-5 \cdot 0 \mathrm{~mm}$ long and $0.4-0.6 \mathrm{~mm}$ wide, with lateral thalline margin. Proper exciple convergent, apically to laterally carbonized, wedge-shaped. Disc very narrow. Hymenium inspersed, 180-230 $\mu \mathrm{m}$ tall. Ascospores 1 per ascus, brownish, elongateellipsoid, densely muriform, 120-180 × 25$35 \mu \mathrm{m}, \mathrm{I}+$ red-brown.

Chemistry. No lichen compounds detected.

Remarks. Platygramme platyloma is characterized by conspicuous lirellae with the proper exciple laterally wedge-shaped and carbonized, a narrow disc and thick labia, large muriform ascospores $(120-180 \times 25-$ $35 \mu \mathrm{m}$ ), and the absence of lichen substances. It occurs in Australia, Indonesia and Japan (Nakanishi et al. 2003; Archer 2006). It is first reported from China in the present paper.

Specimens examined. China: Fujian: Jianou County, Wanmulin, 420-430 m, 2007, Meng Qing-Feng FJ1020 \& FJ1221 (LHS). 


\section{Platygramme pudica (Mont. \& Bosch) M. Nakan. \& Kashiw.}

Bull. Natn. Sci. Mus., Tokyo, Ser. B, 29: 89 (2003).Graphis pudica Mont. \& Bosch, in Junghuhn, Plantae funghuhnianae, 4: 474 (1855).

(Fig. 4G-I)

Thallus crustose, corticolous, upper surface matt, rough.

Apothecia lirelliform, numerous, single, curved or sinuous, $1 \cdot 0-5 \cdot 0 \mathrm{~mm}$ long, $0 \cdot 5-$ $0.8 \mathrm{~mm}$ wide, prominent, black, with lateral thalline margin. Proper exciple convergent, laterally carbonized, red-brown in the base. Hymenium inspersed, 180-250 $\mu \mathrm{m}$ tall. Ascospores 1 per ascus, pale brownish, elongate or ellipsoid, muriform, 20-25 $\times$ 5-6-locular, 150-180 × 18-25 $\mu \mathrm{m}, \mathrm{I}+$ red-brown.

Chemistry. Echinocarpic acid (major) and conechinocarpic acid (minor).

Remarks. Platygramme pudica is characterized by conspicuous lirellae with a laterally carbonized proper exciple and closed and thickish labia, large muriform ascospores (120-180 $\mu \mathrm{m}$ long) and the presence of echinocarpic acid. It occurs in Australia, Indonesia and Japan (Nakanishi et al. 2003; Archer 2006). This species is reported here from China for the first time.

Two species reported from Fujian province, Phaeographina elaeoplaca A. Zahlbr. and Ph. granulans A. Zahlbr., with large fuscescent muriform ascospores and sessile lirellae, and with concealed disc and thick labia (Zahlbruckner 1932), appear to belong in Platygramme. They are very similar to Platygramme pudica, but differ slightly in ascospores size, with the ascospores of Phaeographina elaeoplaca being 110-120 × 30-32 $\mu \mathrm{m}$ and $P$. granulans $140-160 \times 29-31 \mu \mathrm{m}$ (Zahlbruckner 1932). As we have not yet investigated the types of these species, we refrain from formally proposing them as synonyms.
Specimens examined. China: Fujian: Jianou County, Wanmulin, 420 m, 2007, Meng Qing-Feng FJ856 (LHS); 600 m, 2007, Li fing FJ1000 (LHS) .

The authors are grateful to Dr Alan W. Archer and Dr Robert Lücking for help with identifications, and for valuable comments and discussions. The National Natural Science Foundation of China (No. 31093440 and 31270066) and the Ministry of Science and Technology of China (No. 2006FY110500-5) are thanked for their financial support.

\section{REFERENCES}

Archer, A. W. (2006) The lichen family Graphidaceae in Australia. Bibliotheca Lichenologica 94: 1-191.

Kirk, P. M., Cannon, P. F., Minter, D. W. \& Stalpers, J. A. (2008) Ainsworth and Bisby's Dictionary of the Fungi 10th edn. Wallingford: CAB International Publishing.

Li, J. (2010) A study of the Graphidaceae in Hainan Island. M. Sc. thesis, Shandong Agricultural University, China.

Lumbsch, H. T. \& Huhndorf, S. M. (2007) Outline of Ascomycota - 2007. Myconet 13: 1-58.

Mangold, A., Martín, M. P., Lücking, R. \& Lumbsch, H. T. (2008) Molecular phylogeny places Thelotremataceae within Graphidaceae (Ascomycota: Ostropales). Taxon 57: 476-486.

Miao, X. L., Jia, Z. F., Meng, Q. F. \& Wei, J. C. (2007) Some species of Graphidaceae (Ostropales, Ascomycota) rare and new to China. Mycosystema 26: 493-506.

Müller Argoviensis, J. (1880a) Lichenologische Beiträge 10. Flora 63: 17-45.

Müller Argoviensis, J. (1880b) Lichenologische Beiträge 11. Flora 63: 259-290.

Müller Argoviensis, J. (1882) Lichenologische Beiträge 15. Flora 65: 291-402.

Nakanishi, M., Kashiwadani, H. \& Moon, K. H. (2003) Taxonomical notes on Japanese Graphidaceae (Ascomycota), including some new combinations. Bulletin of the National Science Museum, Tokyo 29(2): 8390.

Nylander, W. (1863) Lichenographiae Novo-Granatensis Prodromus. Acta Societatis Scientiarum Fennicae 7: 415-504.

Staiger, B. (2002) Die Flechtenfamilie Graphidaceae. Bibliotheca Lichenologica 85: 1-526.

Zahlbruckner, A. (1932). Neue Flechten - XI. Annales Mycologici 30: 427-441. 